The Quarterly Journal of Austrian Economics

Volume 22 | NO. 2 | 271-297 | SuMMER 2019 WWW.QJAE.ORG

\title{
Desocialization of EnTERPRises: EMPOWERING VENEZUELANS
}

\author{
Rafael Acevedo, Luis Cirocco, and Lorca-Susino María*
}

JEL Classification: B53, E32, E42, E58, G21

АвsтRAct: One of the fundamental conditions for overcoming the economic disaster in Venezuela and being sure that a new government could not snatch away economic freedom again, is the desocialization of the economy. Following Rothbard (1992), we propose one of the required steps to achieve a real free market economy in a post-socialist Venezuela. In this paper we analyze, based on previous experiences, how to desocialize enterprises in this country, as well as the historical skepticism that socialist politicians, media, and economic elites have created against the capacities of Venezuelans to manage their own property. In addition, we provide a draft of a privatization law that minimizes the presence and control of government in this process, a requirement because of the historical trend of corruption and cronyism of all Venezuela's governments. Also, we provide a general description of our proposal of distributing among Venezuelans by birth and legal age, all special taxes and royalties that oil enterprises have to pay to governments in such a way as to starve

\footnotetext{
* Rafael Acevedo (Rafael.Acevedo@ttu.edu) is Research Associate in the Free Market Institute at Texas Tech University, Founder-Director of Econintech.org, and Associate Professor at Universidad Centroccidental Lisandro Alvarado. Luis Cirocco is Lecturer at Universidad Centroccidental Lisandro Alvarado and Founder-Director of Econintech.org. Lorca-Susino María is Professor at the University of Miami and Senior Researcher at Econintech.org.

We thank Professor Hugo Faría who helped us with an early version of this paper. Also, we thank Professor Robert Murphy for his valuable comments and suggestions on this desocialization proposal. Finally, we thank the Mises Institute and the Free Market Institute at Texas Tech University that supported Rafael Acevedo to attend the 2019 AERC in Auburn, Alabama, and all participants who offered suggestions during the conference.
} 
the government and consolidate its fiscal dependence with citizens to strength democracy and liberty. Finally, we conclude that even though it is fundamental, it is not enough just to desocialize enterprises, but also to apply other radical freemarket policies oriented to increase the individual liberties and minimize as much as possible the State.

\section{INTRODUCTION}

$\mathrm{V}$

enezuelans have become accustomed to the view whereby oil and all natural resources belong to the citizens. The mercantilist and socialist media has broadcast and instilled this false idea. The educational system also espouses this erroneous narrative. However, Venezuelans have neither received the proceeds from oil extraction, royalties, taxes and dividends nor been allowed to possess equity shares in the business. On the contrary, because Petróleos de Venezuela Sociedad Anónima (PDVSA, Venezuela's oil company) is a state-owned company, governments are the only direct recipients of those benefits, which confers upon them a tremendous economic power and considerable independence from Venezuelan tax payers.

State ownership of the commanding heights of the economy is not an original policy created in the Chávez-Maduro regime, but an exclusionary economic institution resulting from an increasingly dominant combination of democratic socialism and mercantilism implemented by elites in power decades before the advent of Chávez (Faría and Filardo 2015). With such a huge economic power concentrated in the hands of political and economic elites, representatives of "the socialism of the $21^{\text {st }}$ century" have been able to promote a varied array of destabilizing activities abroad and to increase their power hold in the country, which has morphed into an internationally recognized tyranny. Hence the prescience of Mises's wisdom:

If control of production is shifted from the hands of entrepreneurs, daily anew elected by a plebiscite of the consumers into the hands of the supreme commander of the 'industrial armies' or of the 'armed workers', neither representative government nor any civil liberties can survive. (Mises 2008). 
This paper, which is also inspired by (Rothbard 1992), abides by the principles of not confiscating people's money, keeping taxes as low and simple as possible, and not allowing government ownership of firms. Furthermore, following the general approach to the privatization process argued in (Acevedo 2018), we present a proposal to desocialize not only PDVSA but all Venezuela's state-owned companies and assets.

We understand that this process is difficult but not impossible to apply. In 2017 Transparencia Venezuela reported 526 state-owned companies. Therefore, other structural reforms necessarily have to accompany such property devolvement from the state domain to the private sphere; nonetheless, we will develop them in separate papers: monetary freedom, freedom to trade, rule of law and independence of the judicial system, flexibility of labor laws, minimization of government expenditures, and the systematic privatization of public services, among others.

In this paper, we explain the relevancy of desocializing enterprises in Venezuela and propose a desocialization law. In a nutshell, firstly, we discuss the historical skepticism on the capacities of Venezuelans to enjoy total economic freedom and be real shareholders of the enterprises currently run by the state. Secondly, we analyze the historical process of desocialization in countries with characteristics similar to those of today's Venezuela. Thirdly, we propose a desocialization law justified with the socialist rhetoric that claims Venezuelans are the owners of the companies, thus to convert this fiction into reality, putting an end to deceptive and selfserving socialist narratives.

In addition, this paper provides a preliminary exploration of the issue of equally distributing among Venezuelans taxes and royalties that corporations in the oil sector are today legally forced to transfer to the government. The final goal is to starve the government constraining it to live off the people, a necessary condition for the firm establishment of the rule of law and democracy, contributing to replace the currently perverse practice whereby the people live off the government (Faría 2008).

Finally, we conclude that it is better to distribute shares among all Venezuelan citizens by birth aged eighteen years or older, while selling a relevant stake to foreign and domestic investors 
to attract managerial expertise. We contend that our proposal is better adapted to Venezuela's institutional fragility than if we were to adopt other well-known alternatives implemented by Eastern European countries and England under the Thatcher government.

\section{SKEPTICISM ON THE CAPACITIES OF VENEZUELANS: A HISTORICAL CURSE?}

In this section, we explore the roots of the belief, mainly disseminated by politicians and certain scholars, that Venezuelans are not capable of handling their own freedom and wealth in a proper manner. It is important to understand the origin of that stance because when we publicly state our proposal on the effective distribution of shares among all Venezuelan citizens by birth, aged eighteen years or older, we have faced hard skepticism, based upon an alleged lack of knowledge or ability of the average people.

Such underestimation is widespread and not only an exclusive characteristic of politicians and other elites. On social media, the lack of trust concerning how beneficiaries would manage their shares is commonly expressed. The populist rhetoric, implemented since 1958, has instilled a strong bias, to the point that there are people who do not believe in the power of healthy incentives and individual freedom but do believe in bureaucrats and other elitist groups deciding on behalf of all citizens. Nevertheless, this situation has a historical root since politicians and power elites have always undervalued the ability of Venezuelans.

After a brief review of Venezuela's history, it is relatively easy to understand that the bulk of the independence heroes did not embrace liberal or libertarian ideas at all. The father of the nation, best known as the "Liberator," Simón Bolívar, stated "Generally speaking, our fellow citizens are not yet ready to take on the full and independent exercise of their rights, because they lack the political virtues marking the true citizen of a Republic" (Bolívar [1812] 2003a, 6)

Nonetheless, that was not the only sentence expressing reluctance to believe in his fellow countrymen which the Liberator stated in his life. "Until our compatriots acquire the political skills and virtues that distinguish our brothers to the north, entirely popular systems, 
far from being favorable to us, will, I greatly fear, lead to our ruin" (Bolívar [1815] 2003b, 23). He also said:

Freedom, says Rousseau, is a succulent food but hard to digest. Our weakened citizens will have to strengthen their spirits mightily before they succeed in digesting the healthful nourishment of freedom. Their arms and legs numbed by chains, their sight dimmed in dark dungeons, and stricken by the plague of servility, will they ever be capable of marching with firm steps toward the august temple of Freedom? (Bolívar [1819] 2003c, 34)

Another sentence attributed to Bolívar, showing the dawn of this "historical curse," is: "these gentlemen believed that they were in Greece, building air republics that are not consistent with the situation and reality of the Venezuelan people, not prepared for the supreme good of freedom" (Acevedo and Andrade 2018, 1). In this statement, Bolívar referred to the people who wrote the first constitution of Venezuela in 1811, which was-by the way-federalist and "inspired in the US constitution and the politic liberalism of that moment" (Acevedo and Andrade 2018, 1).

Aguiar $(2018,1)$ argues that Bolivar's sentence in Cartagena in 1812, "the Venezuelan people, not prepared for the supreme good of freedom," has been used and applied in the political context in Venezuela in at least two specific moments, 1959 and 1999. Venezuelan politicians and power elites have used-and keep using - the same phrase to justify the need for a "big, powerful and indulgent dad" - represented by a big state, and a person-the president-whom people have to trust and let decide everything on behalf of everybody.

It was in 1821 when, finally, the independence of Venezuela was reached. Nevertheless, as Faría and Montesinos $(2016,214)$ state “... while Americans founders wanted freedom, Venezuelan generals (caudillos) wanted independence from Spain.... Venezuela's independence was established in 1821 by European descendants and for European descendants."

From 1821 to 1957, Venezuela did not embark on a "real" democracy as it did from 1958-with all of its weaknesses and defects. Before this year, many caudillos-who took power and control of the nation through revolts and/or incipient forms of 
democracy-ruled the country. Other particular characteristics of this term were political and constitutional uncertainties-25 constitutions were "made to cover the desires and needs of the "caudillo" who ruled the country... federalism was increased and decreased depending on the interests of the government" (Acevedo and Andrade 2018, 1). Nevertheless, in the first half of the $20^{\text {th }}$ century, Venezuelans tasted just one part of freedom, Acevedo and Cirocco $(2017,5)$ state, about the 1914 to 1957 timeframe:

...during those years, of the - five presidents we had, four were dictators and generals of the army. Our civil and political rights were restricted. We didn't have freedom of the press, for example; we didn't have universal suffrage. But, while we lived under dictatorships, we could at least enjoy high levels of economic freedom.

When Rómulo Betancourt, a Social Democrat, won the presidential election in December 1958, the democratic era started in Venezuela. For the first time, citizens enjoyed civil and political rights that did not exist before, nevertheless, such "gifts" of democracy came along with a cost, economic freedom. Acevedo and Cirocco $(2017,6)$ said about Betancourt that "he started destroying the economic institutions we had by implementing price controls, rent controls, and other regulations we hadn't had before. On top of that, he and his allies created a new constitution that was hostile to private property." The worst of all this is that, currently, Betancourt's admirers and a great number of social media influencers still justify those policies, saying that Venezuelans were not prepared to enjoy total freedom.

In addition to the politicians and elites' arrogance that underestimates the capacities of Venezuelans, we found other potentially limiting factors for the implementation of our proposal, which involves embracing high levels of economic freedom: cultural factors such as trust in others ${ }^{1}$ and the gap between individualism and collectivism; ${ }^{2}$ the historical origin of the country's laws; ${ }^{3}$ and the legacy of human capital. ${ }^{4}$

\footnotetext{
${ }^{1}$ See Arrow (1972).

${ }^{2}$ See Heine (2018).

${ }^{3}$ See La Porta, Lopez-de- Silanes, and Shleifer (2008).

${ }^{4}$ See Faría and Montesinos (2016) and Bennett et al. (2017).
} 
Faría and Montesinos $(2016,225)$ argue about the importance of the above-mentioned factors. First, trusting others is necessary to embrace economic freedom, but "Venezuela is among the countries of the world with the lowest trust level." With regard to the gap between individualism and collectivism, these authors state that individualistic societies privilege natural rights while collectivistic societies create a population characterized by conformity and "discourage individuals from dissent and standing out." ${ }^{5}$ Not surprisingly, on measuring individualism, Venezuela is located in the lowest quartile among the rated countries. The origin of a country's legal system can explain the level of state meddling: French civil legal tradition allows more interventionism than the English common law system. Venezuela, these authors say, "can be construed as an extreme case of a country with a legal system originating in French civil law" (Faría and Montesinos 2016a, 226). There is "strong evidence suggesting that cognitive skills, a proxy for the quality of education, have a systematic positive effect on the quality of economic institutions" (Faría and Montesinos 2016, 227), which represents another serious problem because, as they also state, "Lamentably, a great misfortune still plagues Venezuela's educational quality... Venezuela within Latin America ranks next-to-last in translating years of schooling into cognitive skills, as measured by international test scores" (Faría and Montesinos 2016, 227).

Finally, the context explained in this section cannot be omitted: the bias against freedom and the distrust regarding individual capacities that the historical and political processes have created, with the intent to preserve an omnipotent, interventionist and socialist state assuring the monopolistic management and control of power and of the commanding heights of the economy.

\section{HOW TO DESOCIALIZE ENTERPRISES IN VENEZUELA}

At this moment (circa March 2019), Venezuela is one of the most commented news stories around the world. President

\footnotetext{
${ }^{5}$ Individualistic cultures prefer rules applied to everyone, whereas collectivistic cultures emphasize friendship for the administration of justice, see Bennett et al. (2019).
} 
Trump's administration in the US and at least 30 more countries are leading efforts to help Venezuelans recover freedom. Nonetheless, this attempt seems to just focus on the "political freedom" arena, because the recovery of "democracy" is apparently the unique objective. Sadly, Venezuela has experienced that just democracy is not enough for long-run prosperity. Indeed, Venezuelans enjoyed such a political system for more than 40 years, but rooted in an omnipotent state, overwhelmingly independent of its citizens in fiscal terms and considered the "big dad" (Acevedo and Cirocco 2017, Faría 2019). In our view, this has been the main cause of the progressive deterioration leading to the current tyranny, a cause that will continue even in the case of a potential change of the rulers.

Since the main objective of this paper is to propose a privatization program-based upon the Austrian School's view, to the best extent possible-it is important to start our theoretical framework by reviewing the specialized literature on this matter. Rothbard $(1992,66)$ shows the guidelines that we have adapted after considering the particular situation of Venezuela. He argues that "you cannot plan markets" in a desocialization strategy and that the only thing you can do is "set people free so that they can interact and exchange, and thereby develop markets themselves" (Rothbard 1992, 66). He explains the impossibility of planning capital markets, as occurred in the failed attempts of some Western economies to develop stock exchanges. For these reasons, Rothbard $(1992,66)$ explains "stock markets cannot be planned... you cannot have markets in titles to capital if there are still virtually no private owners of capital in existence."

Nevertheless, the history of Eastern European countries demonstrated that some privatization programs have succeeded. For example, the Georgia case, after a Social-Democrat government and some attempts of privatization involving a lot of corruption, cronyism, and political influences, the new real pro- free market government started a privatization program headed by Bendukidze. To the best of our knowledge, it is one of the most successful ones that we have researched during the writing of this proposal. Some other attempts of desocializing enterprises, with relative success, are not difficult to find in recent history. The privatization program headed by Lewandowski in Poland, with 
all its pros and cons, is another clear example that when rulers let free markets rule, things go right.

For the sake of brevity, in this research, we just address the main issue of desocializing the enterprises currently owned and managed by the government. Nevertheless, we develop proposals for similar processes that should take place in other areas, such as taxes and money, in separate papers. We are quite conscious that this is not an isolated action and that, on the contrary, it should be implemented as part of a general plan which minimizes or prevents government's meddling in critical economic issues.

\section{Problems Desocialization of Enterprises Will Face}

In this paper, we try to cover the most relevant privatization topics of Venezuela's enterprises, based upon its current situation; nevertheless, the literature on this matter is wide and varied. Since Venezuela would be in a breakpoint by the moment of a potential implementation of this proposal ${ }^{6}$, we need to analyze the historical problems and failures of such a complex action as privatization. The people and the government implementing our program might understand that desocializing - in any economy - "is almost never painless" (Kikeri and Nellis 2002, 20). Strictly speaking, some attempts at privatizing in other countries have ended in tremendous failures, ${ }^{7}$ because as Carter (2013, 108-09) argues, "privatization involves changing institutional archetypes which structure the governmental, societal, and economic arrangements and behaviors; it can be both challenging and problematic." However, those failures are the proof of what Rothbard (1992) stated: the bulk of Western economists who were consulted on how to desocialize and build a free market economy had to handle not only the obstruction of

\footnotetext{
${ }^{6}$ We admit that the only chance our proposal has to be implemented is that a new real pro- free market government be established. Nevertheless, the political history and the current closeness of the Interim President, the fact that his political party belongs to the International Socialist, and the highly publicized Keynesian "The Morning After" plan, best known in country as "Plan País," make it almost impossible for our desocialization proposal to be considered in the short run. Our hope is that someday, as in Georgia, the free-market principles win not only the battle of ideas but also the political war taking place in Venezuela.
}

${ }^{7}$ See (Li, Wang, Cheung, and Jiang 2011). 
bureaucrats but also their own confusions and misunderstandings about how real free markets function. ${ }^{8}$

Therefore, when a country is breaking the chains of socialism or communism and wants to desocialize, it is not only important to transfer the ownership from the public sector to private hands, but to really implement a free-market economy as well. In a general context, we understand a real free-market economy as one in which the state is limited and minimal, totally dependent on citizens, and unable to intervene in the economy, where natural rights are constitutionally enshrined and highly protected, and where private property and wealth — well created and acquired-are sacred. With such an economy, we are confident that our proposal will overcome the possible cons of privatization that Goodman and Loveman (1991, 4) argue. These authors say, "Neither public nor private managers will always act in the best interests of their shareholders," nevertheless free markets will give managers the incentive to be efficient or, otherwise, competition will push them off the market. Following these authors' reasoning, when the new privatized enterprises have free competition, the presence of other companies will be an excellent factor "to discipline managerial behavior" (Goodman and Loveman 1991, 4). Nonetheless, if a free-market economy is not implemented, although Venezuela's rulers apply any proposal of privatization, "continued governmental involvement will likely be necessary" (Goodman, and Loveman 1991, 5)

Other problems that privatization processes bring along with them are corruption and cronyism. The example of Uganda in the 1990s is representative. The government controlled the complete privatization process, and, although the International Monetary Fund (IMF) and the World Bank (WB) argued that this African country was a great example of economic recovery, and-as Venezuelan Keynesians expect to have- these institutions provided Uganda with hard financial support. ${ }^{9}$ Despite funds and advice provided

\footnotetext{
${ }^{8}$ Rothbard (1992) says: "Western economists have accepted the view that there is no calculation problem under socialism." For this reason a great part of them have failed in their wrong attempts to set up a real free market economy.

9 “The Morning After Plan" or "Plan País" involves borrowing at least 100 billion US\$ from the IMF to finance the recovery of state-owned enterprises, subsidies to producers, and other Keynesian strategies which just represent more state
} 
by international donors, the lack of transparency and ability to check the "government divestiture decisions, privatization could be a highly manipulative process" (Tangri, and Mwenda 2001, 118). As the cited authors state, the lack of punishment in corruption and cronyism cases has left the door open for politicians to continue with this improper behavior. "Discriminatory and corrupt privatizations have been common because political leaders have wanted public companies to be divested to their favored clients" (Tangri and Mwenda 2001, 118).

Nevertheless, Uganda is not the only example of these vices. We admit that it is almost impossible to totally eradicate corruption and cronyism from post-socialist and post-communist economies immediately, which is a reason why limiting the independency and management of the state is needed in the process. Webriefly comment on the transition of the former Soviet Union, and some Central and Eastern European privatization processes (perhaps, the biggest in history) to understand the problems they faced. (Kaufmann, and Siegelbaum 1996, 419-20) counted the terrific number of 188,000 among small, medium and large scale enterprises privatized, but they also stated that "corruption has reached endemic levels in the transition economies." In Georgia, the privatization process

interventionism. Some economists who are also deputies of the National Assembly-belonging to the opposition faction-have declared that public expenditures will not be decreased but exponentially increased to "re-activate" the economy. Haussman, the "father of this plan," is a former Minister of the Central Planning Economy Office of the second term of Carlos Andrés Pérez, and currently Director of the Center of International Development (CID) at Harvard. He has publicly declared that the way he sees the Venezuelan economy now is analogous to a taxi driver who has his car but no money to buy gasoline, so with his plan he will be "given" the gasoline for free. We accept that, at this moment, the critical conditions of Venezuela require the implementation of some social helps, but we would agree if such helps were provided through direct subsidies; in other words, by subsidizing the demand and not the supply. In a nutshell, this plan is just the second chance of a failing plan applied by Keynesians in Venezuela in the 1980s, according to which the state will continue to be the great owner of the commanding heights, boost the economy through public expenditure financed with more debt, monopolize the monetary market, have the power to control and intervene, and promote a false free-market economy. The Keynesian plan mainly aims at solving short term problems associated with the business cycle, while paying little attention to the economic institutional quality which determines whether the economy experiences high and sustained economic growth (Cirocco, Faria, Morales, and Navarro 2019). 
started after its independence in 1992; nevertheless, corruption and cronyism surrounded it up to the "Rose Revolution," when the political fight was won by Mikheil Saakashvili, who assigned Kakha Bendukidze as Minister of Economy (Burakova and Lawson, 2013).

However, history demonstrates that desocializing a country involves facing some problems. But there are also good examples of how to succeed with the lowest—or null—state interventionism, support of the rulers, and "setting their subjects free, as fast and as completely as it takes to unlock their shackles" (Rothbard 1992, 66). Briefly, our desocialization proposal will face some problems, but they will be overcome with the implementation of a real freemarket economy and by minimizing the presence, influence and management of the state in the process. This is an indispensable condition to succeed in any desocialization plan for Venezuela, as Rothbard $(1992,66)$ indicates "freeing only a few areas at a time, will only impose continuous distortions that will cripple the workings of the market and discredit it in the eyes of an already fearful and suspicious public."

\section{Why Desocialize Enterprises?}

A devastated economy is the worst thing people can live through. The latest statistics and indicators show that in Venezuela the scarcity of products have risen to 80 percent, hyperinflation forecasts by the IMF reached the 10 million percent level for 2019 (IMF, 2018), and the humanitarian crisis is internationally recognized. When basic goods and services are not affordable for citizens, they start to think about how to solve that problem and, believe it or not, most of the people find the answer in a phrase attributed to Rothbard: Privatize Everything!

Why is it so important to privatize? (Rider and Zajicek 1995, 135) explain a paramount advantage: firms "become more efficient and more responsive to their customer's needs." There is no doubt that private management is far better than governmental management, and "the stimulus that private ownership gives to innovation" (Rider and Zajicek 1995, 135) is important to overcome the problems that a post-socialist country will come across. Another reason is to reduce the size of the state and stop interventionism in 
the economy; ${ }^{10}$ indeed, this should be the most important goal of any post-socialist or post-communist country.

Hoppe (2011) suggests that privatization is required even to avoid all conflicts among people, given scarcity, and that the consequent private property must be clearly defined for such purpose. Hazlitt (1996, 210), in turn, indicates that public wealth derives from property in private hands, used for the production of goods and services for the market, and it serves people "just as much as-in fact, far more effectively than-if it were owned and operated by the government."

As we pointed out, transferring the property of enterprises owned and managed by governments to private hands is a process sensitive to corruption, cronyism and other problems, which can be minimized if appropriate actions are followed. But if prosperity, efficiency and the total dependence of the government on its citizens is the path a country wants to go through, privatization is one of the most important plans to be performed.

\section{Which Is the Best Method to Desocialize Enterprises?}

Another great problem involved in this process is how to privatize, which we decided to analyze in a different section. As we have argued before, the literature in this field is wide; nevertheless, we focused our efforts and research on the current situation of Venezuela. This is why we do not include some experiences, although the United States, Canada, the United Kingdom, and other institutionally better countries around the world have great examples of how governments manage and head the privatization processes. ${ }^{11}$ Venezuela is very far away of the reality and context where those examples succeeded. Countries included in this paper are the closest to the social, political, and economic conditions of Venezuela.

Rothbard $(1992,73)$ explains the egalitarian handouts method, meaning that each "citizen receives in the mail one day an aliquot share of ownership of various previously state-owned properties,"

\footnotetext{
${ }^{10}$ See Rider and Zajicek 1995, Carter 2013, Lewandowski 1996, and Brooks 2004.

${ }^{11}$ See McDavid (1985), Moore (1992), Brooks (2004), Brunsdon and Corssmit (1998), David (1988), McMeekin (1999), and Goodman and Loveman (1991).
} 
but he does not agree with this procedure because "the number of people would be too much and shares too few to allow every person to have a share" (Rothbard 1992, 73). He also comments about the voucher system in which "each citizen receives basic certificates, which could be exchanged for a certain number or variety of shares" (Rothbard 1992, 73). However, Rothbard does not agree with this method either, but proposes and supports the homestead principle that states "assets are to devolve, not upon the general abstract public as in the handout principle, but upon those who have actually worked upon these resources: that is, their respective workers, peasants, and managers" (Rothbard 1992, 73). Another method Rothbard analyzes is the public auction, according to which the government sells everything to the highest bidder; nevertheless, he immediately asks, "Why does government deserve to own the revenue from the sale of these assets?" (Rothbard 1992, 75). Finally, the fourth principle analyzed in his paper is returning all stolen - or nationalized or expropriated-properties to their legitimate owners, but he says that for many reasons, "there are no owners to identify" (Rothbard 1992, 75).

Following (Rider and Zajicek, 1995), there are at least six common methods of privatization in post-socialist or post-communist economies. The voucher method, explained above; it has been implemented with some varieties like mutual funds and freedom to trade vouchers. Notwithstanding, this method should be highly popular among population, it faces some cons. It does not report any profit to the government-which is a strength in our viewand populist politicians-and interest groups-argue that it is acceptable to scam people who do not have any financial knowledge and who would value a couple of coins more than a share. Nonetheless, the National Mutual Funds applied by Lewandowski in Poland, ${ }^{12}$ and other proved settings in different countries-like the non-tradable condition for a couple of years-have demonstrated that it is possible to overcome those problems.

The public auction is one of the best methods to privatize small enterprises, but the great problem is that transition economies are vulnerable to be corrupted by revealing relevant information and directly assigning to favorite bidders. Nonetheless, there is nothing

\footnotetext{
${ }^{12}$ See Hunter and Ryan (2004), Rider and Zajicek (1995), and Lewandowski (1996).
} 
that transparent auction systems and solid free market institutions cannot overcome. Georgia, after its independence in 1992, began a privatization process but, as Lawson, and Powell (2018) say, it "was mostly corrupt and limited. Comprehensive privatization did not begin until 2004, when Kakha Bendukidze declared that 'everything was for sale except Georgia's honor.'” Bendukidze started a public auction with no limitations or restrictions; everybody could bid for any asset, even Russians with the resentments that Georgians could have against them. Everyone was able to check out on the www. privatization.ge website who bid, how much, and what the last bid was. Under Bendukidze's leadership, privatization was a complete success because he eradicated corruption and cronyism (Lawson and Powell 2018).

The third method that Rider and Zajicek (1995) present is employee privatization, which falls under the homestead principle supported by Rothbard (1992). The problem with this method is that if the privatization is only to employees, the "desocializers" might consider that the bulk of the beneficiaries would be former communists-or socialists. ${ }^{13}$ In other words, the great part of the employees in a former socialist or communist country belonged to the former government. The fourth method is the Initial Public Offering, which allows government to raise funds, but the results have been "massive oversubscription... it is a costly and time-consuming procedure... high transaction costs and public discontent" (Rider and Zajicek 1995, 138), and finally, those who really benefit from this method are "insiders and a few professional speculators" (Rider and Zajicek 1995, 138).

The Liquidation and the (direct) Sales to Foreign Investors are the last methods that Rider and Zajicek (1995) explain. Despite some advantages of these mechanisms (for example, liquidation allows to divide and sell the entity in several parts and foreign investors have "deeper pockets than domestic residents" (Rider and Zajicek

${ }^{13}$ Even people who supported or committed human right crimes, or foreigners from "friendly countries" of the former governments, i.e. in Venezuela there are a lot of Venezuelan military personnel, and Cuban military personnel, and civil employees who are employees and managers from many years ago in some "strategic enterprises" such as the oil industry and others. Do they deserve-more than the rest of Venezuelans - to be the new owners of enterprises such as PDVSA or some other multi-billion dollar company? 
1995, 139), the disadvantages - mostly related to cronyism and corruption - and then, bad experiences related to them are greater than the pros.

The proposal that we formalize in this paper follows Acevedo's (2018) plan, which encompasses minimum state intervention, the impossibility for the government to vote, seventy per cent of the shares delivered to Venezuelans, special conditions for the expropriated people, certain limitations on the percentage of shares owned, and a special restriction of three years on selling or transferring shares for all Venezuelans who previously received them as part of the process.

We agree with the four general recommendations that Rothbard (1992) provides about desocialization processes: 1) drastic reduction in taxes, government expenditures, and government employment; 2) returning property of the assets owned by the government to the original expropriated owners or their heirs, or granting shares to productive workers and peasants who had worked on these assets; 3) honoring complete and secure property rights in the sense of providing complete freedom to transfer property; and 4) depriving the government the power to create new money. However, for reasons of applicability due to the current situation of the countryone of chronic widespread corruption, at extreme levels, particular cultural characteristics, and the fact that industries were effectively bought by the government when they were nationalized-and in light of previous experiences of other countries undertaking similar privatization processes, some restrictions are included in our proposal, especially concerning points 2) and 3) of Rothbard's paper. Moreover, if expropriated owners were fully compensated, then it is natural that the legitimate owners should be the Venezuelans.

\section{THE DESOCIALIZATION OF ENTERPRISES LAW PROPOSAL}

This paper is aimed at proposing a desocialization of enterprises law in light of the current situation of Venezuela. After analyzing relevant experiences in former communists and socialist countries, we have developed this draft of law with the intent to overcome some errors captured in its previous attempts, as in Acevedo 
(2018). It is worth remarking that this program just encompasses desocializing enterprises and assets currently managed by the government, although the desocialization of other fundamental pillars of the Venezuelan economy is of paramount importance as well. Gradual steps towards this ultimate goal of desocializing an economy are not effective. On the contrary, as Rothbard $(1992,69)$ argues, those steps "...could, and should, be instituted immediately and all at once."

Circa March 2019, Venezuela is going through serious economic problems and aiming at potentially getting rid of a socialist and tyrannical regime and at establishing a new government that will surely fall into the "charms" of a democratic socialism with total control of the commanding heights of the economy, once again. From a humanitarian perspective, a change in the Venezuela's political arena would be a gain, since the current humanitarian crisis would be relieved. Nonetheless, our desocialization proposal will continue to be seen-we greatly fear-as the work of some promoters of freedom who intend to lead the country towards a real path of prosperity, but not taken into consideration.

\section{A Draft of the Desocialization of Enterprises Law}

\section{Generalities}

1. The scope of this law involves all State-Owned Enterprises (SOE) and State-Owned Assets (SOA).

2. The Beneficiaries (B) are all Venezuelans by birth and aged at least 18 years at the moment when the desocialization process takes place, residents or not in Venezuela. They will have to enroll in the private national or international financial institution of their preference, which will represent them throughout the process.

3. The Desocialization Board (DB) will head the process.

3.1 The DB will be formed as follow: one (1) representative per financial institution having at least 4 percent of the total Venezuelans enrolled in the process; one (1) representative per branch of the state: executive, judicial and legislative. 
3.2 All representatives have "voice" in the process, but just financial institutions' representatives have the right to vote in a proportion defined by the number of Venezuelans they represent.

3.3 If a financial institution does not represent 4 percent of the total Venezuelans enrolled in the process, it can delegate its representation functions to another institution.

3.4 All official and unofficial meetings of the DB will be broadcast live, recorded, and published, for transparency purposes.

3.5 All communications among the representatives will be considered public and will have to be recorded.

4. A Financial Rescue Fund (FRF) will be created as a fund managed by the DB to rescue some SOEs and pay liabilities. Funds will come from the process itself.

Classification

5. The DB will categorize the SOEs and SOAs into six groups:

5.1 Desocialization Group: those SOEs fulfilling the desocialization process requirements.

5.2 Rescuable Group: those SOEs that can reach the requirements of the Desocialization Group upon following this process.

5.3 Public Auction: those SOEs that this process could not rescue and SOAs not classified as Clearance Assets.

5.4 Clearance Assets: all SOAs totally depreciated or in junk conditions.

5.5 Expropriated Assets or Enterprises: all those enterprises and/or assets expropriated or nationalized against the will of their former owners.

5.6 Social Assets: all those assets related to social programs given to citizens with no full property.

\section{Procedure}

6. The Present Value of all certified reserves of natural resources of each SOE and/or SOA will be included in their respective accountability. 
7. For Social Assets: the DB will immediately transfer, along with the corresponding tenure, the full property of the asset to the citizens, without restrictions in the rights to sell, mortgage, build, or rent. Citizens will not pay any fee for the property transfer process.

8. For Expropriated Assets or Enterprises: The DB, based upon consistent proofs, will proceed as follows

8.1 If the governmental administration indemnified the former owner by paying a price lower than the real value of the asset at that moment, the $\mathrm{DB}$ will transfer the property back to the former owner. The former owner will return the surplus resulting from the difference between the current value and the received amount minus the difference between the value at the moment of the expropriation and the received amount; if that final difference is negative the DB will transfer the property immediately to the former owner with no fees, and the difference will be paid through the FRF.

8.2 If the administration did not indemnify the former owner for the expropriated assets or enterprises, the DB will immediately transfer the property to their former owners. If the difference between the current and past value is negative, the DB will pay such difference through the FRF.

9. For Clearance Assets: the DB will open a public sale process, using a technological system based on blockchain, and sell these assets in batches. The system will be transparent, with full public access to information about prices, buyers, and sale conditions. Up to 25 percent of the raised funds will be destined to pay the fees and other expenses associated with this process, including those related to the DB. The DB will deposit the rest of the funds in the FRF.

10. For Public Auction: the DB will auction each SOE and SOA through a technological system based on blockchain. The system will be transparent, with full public access to information about prices, buyers, and sale conditions. Up to 12.5 percent of the raised funds will be destined to pay the fees and other expenses associated with this process, including 
those related to the $\mathrm{DB}$. The $\mathrm{DB}$ will deposit the rest of the funds in the FRF.

11. For the Rescuable and Desocialization Group: the DB will establish a desocialization date for each one and estimate liabilities for each company, even considering the human resources liabilities, and including them in the balance sheet up to the date of the property transfer.

\section{Desocialization Process}

12. For companies with Total Assets greater than Total Liabilities, by 30 percent or more: the DB will capitalize liabilities and transfer the property as follows

12.1 Through a liabilities-equity swap, each creditor, and employee, will obtain an exact amount in shares than the enterprise owes them.

12.2 70 percent of the rest in identical parts to $B$, in the form of shares.

12.3 The new Board of Directors of the enterprise, elected by the new shareholders through their legal representatives, will sell the remaining 30 percent of the equity with a premium no more than 30 percent, considering the initial restriction in point 16 below. Up to 10 percent of the raised funds will be destined to pay the fees and other administrative expenses associated with the process, including those related to the DB. The DB will deposit the rest of the funds in the FRF.

13. Companies with Total Assets less than Total Liabilities or Total Assets higher than Total Liabilities by less than 30 percent, even 0 percent:

13.1 The DB will determine if creditors can be proportionally paid, with no more than 30 percent of the available FRF at the moment, an amount sufficient to make Total Assets greater than Total Liabilities, by 30 percent or more. The procedure described in point 12 will be followed then.

13.2 If the DB determines that more than the 30 percent of the available FRF is required and that there is at least 
another SOE classified in the desocialization group, then the DB will have to wait up to the end of the process to analyze if this SOE can be rescued through the FRF. If, at the end of the process, this is the last SOE classified in the Rescuable Group and there are enough funds in the FRF, then the DB will use those funds required to accomplish the proportion of Total Assets and Liabilities described in point 13.1. If there are not enough funds in the FRF to accomplish the proportion of Total Assets to Total Liabilities described in point 13.1, and to rescue the last SOE classified as Rescuable, the DB will re-classify it into the Public Auction Group.

Remainder of the Financial Rescue Fund

14. If the desocialization process ends and the FRF still has funds, the DB will proceed as follows:

14.1 It will pay a desocialization process premium, in proportion to the represented $B$, to each member of the DB of the financial institutions. The grand total of this bonus will not be more than the 10 percent of the available funds.

14.2 The rest of the funds will be distributed proportionally among all SOEs that followed point 12 up to the amount of the premium that point 12.3 establishes.

14.3 If, after following point 14.2, the FRF still has funds, the $\mathrm{DB}$ will distribute them in equal parts to $\mathrm{B}$.

\section{Final Considerations}

15. The property of all SOEs and SOAs that this desocialization program encompasses will include the property of the corresponding soil and subsoil.

16. For a term of 3 years, after the day of the official desocialization, neither any person nor any company can buy and / or hold more than 3 percent of the equity of any SOEs desocialized through point 12. Nevertheless, a person or institution can represent, through a legal power, more than 3 percent of the total equity.

17. There is no other limitation to foreigners than the one stated in this law. 
18. New shareholders will be able to immediately transfer, back debts or sell their shares. Nevertheless, those shares given to $\mathrm{B}$ following point 12.2 will be non-negotiable and non-transferable for 3 years from the day that $\mathrm{B}$ receives them.

19. Immediately after the desocialization day of each enterprise, new owners and employees will privately bargain new rules and laws of their labor contract. They can establish new private deals and rules considering or not the national's labor legal framework.

\section{Taxes and Royalties from the Oil Sector Distributed among All Venezuelans}

Following Faría and Filardo (2015) and Faría (2019), the main objective of our proposal is to "starve the government" and make it completely dependent on its citizens. So a crucial and complementary part of our proposal encompasses letting all the oil proceeds, paid in US dollars to governments as taxes and royalties by the transnational companies for the activities they carry out in country, be deposited directly into the accounts of Venezuelans by birth and of legal age. A measure of such nature would reduce the economic power of governments and would force them to come to their citizens to negotiate the tax rate levied on those proceeds. The civil society, in turn, would have more power to demand services of higher quality, and one of the fundamental bases of a long-lasting democracy would have been established: a government with an absolute fiscal dependence on its people. ${ }^{14}$

The delivery of all oil proceeds to Venezuelans confers upon them power and responsibility since it limits the state, on preventing it from directly receiving money which does not result from the efforts of its people; the state, in turn, would only survive by applying a reasonable tax burden to citizens.

We will cover this specific aspect of the reform, in more detail, in a separate paper about desocializing taxes.

\footnotetext{
${ }^{14}$ At present, the government is more than $50 \%$ independent of its people because it directly receives oil proceeds.
} 


\section{CONCLUDING REMARKS}

Although it might seem unorthodox, mainly due to some restrictions imposed, our proposal results from considering the current economic and social conditions prevailing in Venezuela, as well as previous privatization experiences in other countries. Certain aspects of this work are still being explored and/or revisited, so it could be subject to change in the future.

We think that two of the most critical points of discussion are associated with the initial restrictions imposed: 1) the impossibility for a new shareholder to sell his/her shares during the first three years, and 2) the impossibility for a private company or person to purchase more than 3 per cent of the equity.

Previous experiences in other countries, where citizens felt cheated by the new private approach, exchanged their shares for food or alcohol right after obtaining the stock, and started blaming the program before the performance of the privatized companies stabilized, were the main reason to impose the constraint of not allowing selling during the first three years. Nevertheless, it has to be emphasized that this restrictive measure is applicable just to shares received according to point 12.2 of our law proposal. Other forms of acquisition are not affected by this temporary sell restriction (i.e. if employees receive shares as part of their labor benefits).

On the other hand, the impossibility for an institution or person to acquire more than 3 percent of the total equity is another restriction of the proposal, imposed with the intent of avoiding cartelization at the early stages of the privatization process. According to point 16 of the law, besides, any person or institution can represent more than 3 percent of the total assets.

Selling shares in batches to different buyers, selling under futures contracts, actively participating in the company (in the board of directors, for instance), or transferring their voting rights to institutions are options available for the new shareholders, so restrictions should not represent a significant problem.

As stated before, we are still working to cover other aspects of the privatization of the Venezuelan state-owned assets, so this proposal might be subject to change; restrictions could be eliminated or re-adapted as part of the research process. 
Our present work should be framed in a more general approach embracing the deregulation of the labor markets, a radical simplification of the taxation system, the elimination of the minimum wage, the opening of the economy, and the eradication of the state's monopoly of money, among others. At Econintech.org, we are working on all of those margins as well.

\section{REFERENCES}

Acevedo, Rafael. 2018. “La Desnacionalización de las Empresas del Estado." Econintech. Accessed December 12, 2018. https://econintech. org/2018/11/28/la-desnacionalizacion-de-las-empresas-del-estado-por-rafael-acevedo/

Acevedo, Rafael, and Humberto Andrade. 2019. "The Death of Venezuelan Federalism-and the Rise of Socialism." Mises Wire. Accessed April 15, 2019. https://mises.org/wire/ death-venezuelan-federalism- $\%$ E2 $\% 80 \% 94$-and-rise-socialism

Acevedo, Rafael, and Luis Cirocco. 2017. "How Socialism Ruined Venezuela." The Austrian 3, no. 5: 4-7.

Aguiar, Asdrúbal. 2018. "Venezuela, herida en el corazón." Diario Las Américas. Accessed March 20, 2019. https://www.diariolasamericas. com/opinion/venezuela-herida-el-corazon-n4168533

Bolívar, Simón. [1812] 2003a. "The Cartagena Manifesto: Memorial Addressed to the Citizens of New Granada by a Citizen from Caracas." In El Libertador: Writings of Simón Bolivar, ed. David Bushnell. Oxford: Oxford University Press. . [1815] 2003b. "The Jamaica Letter: Response from a South American to a Gentleman from This Island." In El Libertador: Writings of Simón Bolivar, ed. David Bushnell. Oxford: Oxford University Press.

—_. [1819] 2003c. "The Angostura Address." In El Libertador: Writings of Simón Bolívar, ed. David Bushnell. Oxford: Oxford University Press.

Bennett, Daniel, Hugo Faría, James D. Gwartney, and Daniel Morales. 2017. "Economic Institutions and Comparative Economic Development: A Post-Colonial Perspective." World Development 96: 503-19. 
Bennett, Daniel, Hugo Faría, James D. Gwartney, and Carlos Navarro. 2019. "The Role of Culture and Institutions in Economic Development." Econintech Working Paper 201903.

Brooks, Richard. 2004. “Privatization of Government Services: An Overview and Review of the Literature." Journal of Public Budgeting, Accounting $\mathcal{E}$ Financial Management 16, no. 4: 467-91.

Brudson, James, and C. W. Crossmit. 1998. "Privatization of Fairbanks Municipal Utilities System." Government Finance Review 14, no. 4: 25-7.

Burakova, Larisa, and Lawson, Robert. 2013. Georgia's Rose Revolution: How One Country Beat the Odds, Transformed Its Economy, and Provided a Model for Reformers Everywhere. Guatemala: The Antigua Forum Universidad Francisco Marroquín.

Carter, Min. 2013. "Privatization: A Multi-Theory Perspective." Journal of Management Policy and Practice 14, no. 2: 108-22

Cirocco, Luis, Hugo Faría, Daniel Morales, and Carlos Navarro. 2019. "Revisiting: Does Institutions Cause Growth?" Econintech Working Paper 201901.

David, Irwin. 1988. "Privatization in America." In The Municipal Year Book, ed. International City Management Association. Washington D.C.: ICMA.

Faría, Hugo. 2008. "Hugo Chávez Against the Backdrop of Venezuelan Economic and Political History." Independent Review 12, no. 4: 519-35.

— 2019. "Socialist Democracy: Is it Viable?" Pp. 79-89 in Prosperity E Liberty: What Venezuela Needs..., ed. Rafael Acevedo. Miami: Econintech

Faría, Hugo, and Leonor Filardo. 2015. "Venezuela: Without Liberals There Is No Liberalism." Econ Journal Watch 12, no. 3: 375-99.

Faría, Hugo, and Hugo M. Montesinos-Yufa. 2016. “The Critical Role of Economic Freedom in Venezuela's Predicament." Pp. 213-37 in Economic Freedom of the World 2016 Annual Report, ed. Gwartney, James, et al. Vancouver: Fraser Institute.

Goodman, John, and Gary Loveman. 1991. "Does Privatization Serve the Public Interest?" Harvard Business Review 69, no. 6: 26-8, 32, 34-6.

Hazlitt, Henry. 1996. The Conquest of Poverty. New York: Foundation for Economic Education. 
Hoppe, Hans-Hermann. 2011. "The Rationale for Total Privatization." Mises Institute. Accessed February 25, 2019. https://mises.org/library/ rationale-total-privatization.

Hunter, Richard, and Leo Ryan. 2004. "Privatization and Transformation in Poland: An Update." Polish Review 44, no. 3: 919-43.

International Monetary Fund. 2018. "Inflation rate, average consumer prices." Accessed February 23, 2019. https://www.imf.org/external/ datamapper/PCPIPCH@WEO/WEOWORLD/VEN.

Kaufmann, Daniel, and Paul Siegelbaum. 1997. "Privatization and Corruption in Transition Economies." Journal of International Affairs 50, no. 2: 419-58.

Kikeri, S., and J. Nellis. 2002. "Privatization in Competitive Sectors: The Record to Date." World Bank Policy Research Working Paper 2860.

La Porta, Rafael, Florencio Silanes, and Andrei Shleifer. 2008. “The Economic Consequences of Legal Origins." Journal of Economic Literature 46, no. 2: $285-332$.

Lawson, Robert, and Benjamin Powell. 2019. Socialism Sucks: Two Economists Drink Their Way through the Unfree World. Washington, D.C.: Regnery.

Lewandowski, Janusz. 1996. “Poland's Privatization Process: A View from Inside. Interview with Mark Bonamo." Journal of International Affairs 50, no. 2: 573-80.

Li, Kai, Tan Wang, Yan-Leung Cheung, and Ping Jiang. 2011. "Privatization and Risk Sharing: Evidence from the Split Share Structure Reform in China." Review of Financial Studies 24: 2499-525.

McDavid, James. 1985. "The Canadian Experience Privatizing Residential Solid Waste Collection Services." Public Administration Review 45, no. 5: 602-08

McMeekin, Brian. 1999. "Privatization of Flee Management: The Allegheny County, Pennsylvania Experience." Government Finance Review 15, no. 5: 15-18

Mises, Ludwig. 2008. Profit and Loss. Auburn, Ala.: Ludwig von Mises Institute.

Moore, John. 1992. "British Privatization-Taking Capitalism to the People." Harvard Business Review 115-124. 
Rider, Christine, and Edward Zajicek. 1995. "Mass Privatization in Poland: Processes, Problems and Prospects." International Journal of Politics, Culture, and Society 9, no. 1: 133-48.

Rothbard, Murray. 1992. "How and How Not to Desocialize." Review of Austrian Economics 6, no. 1: 65-77.

Transparencia Venezuela. 2017. "The Bolivarian Project Enlarged the Platform of State-Owned Enterprises to Increase Economic, Political and Social Control." Accessed December 12, 2018. https:// transparencia.org.ve/project/the-bolivarian-project-enlarged-the-platform-of-state-owned-enterprises-to-increase-economic-political-and-social-control/

Tangri, R., and A. Mwenda. 2001. "Corruption and Cronyism in Uganda's Privatization in the 1990s." African Affairs 100: 117-13. 